\title{
Lipid Profiles of Blood Serum and Fatty Acid Composition of Meat of Hybrid Duck Fed Diet Supplemented with Noni (Morinda citrifolia) Fruit Meal
}

\author{
Kurniawan $\mathrm{D}^{1}$, Widodo $\mathrm{E}^{2}$, Djunaidi $\mathrm{IH}^{2}$ \\ ${ }^{I}$ Graduate Student, Faculty of Animal Science, University of Brawijaya \\ ${ }^{2}$ Department of Nutrition and Animal Feed, Faculty of Animal Science, University of Brawijaya \\ Veteran St. University of Brawijaya, Malang 65145 Indonesia \\ E-mail: davidkurniawan34@yahoo.co.id
}

(received 07-07-2015; revised 27-07-2015; accepted 21-08-2015)

\begin{abstract}
ABSTRAK
Kurniawan D, Widodo E, Djunaidi IH. 2015. Profil lipid darah dan komposisi asam lemak daging itik hibrida dengan suplementasi tepung buah Mengkudu (Morinda citrifolia) dalam pakan. JITV 20(3): $200-206$. DOI: http://dx.doi.org/10.14334/jitv.v20i3.1187

Mengkudu merupakan salah satu jenis tanaman obat yang mempunyai senyawa bioaktif antioksidan yang berpotensi digunakan sebagai imbuhan pakan pada ternak unggas.Tujuan penelitian ini untuk mengetahui pengaruh penggunaan tepung buah mengkudu sebagai imbuhan pakan terhadap profil lipid serum darah dan komposisi asam lemak daging itik hibrida. Materi dalam penelitian ini adalah itik hibrida persilangan itik peking dan itik khaki campbell berumur 2 minggu sebanyak 120 ekor. Terbagi menjadi 24 unit penelitian, masing-masing berukuran 70x80x40 cm digunakan untuk 5 ekor sampai umur 56 hari pemeliharaan. Setiap unit dilengkapi dengan tempat pakan dan minum pada lantai kandang litter. Pakan penelitian digunakan pakan basal yang disusun sesuai kebutuhan nutrisi itik pedaging sesuai standar NRC (1994). Metode penelitian yang digunakan adalah uji biologis pada ternak yang dirancang dengan menggunakan Rancangan Acak Lengkap (RAL) yang terdiri dari 4 perlakuan dan 6 ulangan yaitu P0 (Pakan basal tanpa tepung mengkudu); P1 (Pakan basal + tepung mengkudu $1 \%$ ); P2 (Pakan basal + tepung mengkudu $2 \%$ ); P3 (Pakan basal + tepung mengkudu $3 \%$ ). Data yang diperoleh dianalisa ragam menggunakan Rancangan Acak Lengkap one-way ANOVA dan apabila terdapat perbedaan signifikan dilanjutkan dengan analisa beda nyata Duncan's. Hasil penelitian menunjukkan bahwa penggunaan tepung buah mengkudu sampai level 3\% sebagai imbuhan pakan tidak memberikan perbedaan $(\mathrm{P}>0,05)$ pengaruh terhadap profil lipid serum darah dan komposisi asam lemak daging itik hibrida.
\end{abstract}

Kata Kunci: Buah Mengkudu, Fitobiotik, Asam Lemak, Lipid Darah

\begin{abstract}
Kurniawan D, Widodo E, Djunaidi IH. 2015. Lipid profiles of blood serum and fatty acid composition of meat of hybrid duck fed diet supplemented with Noni (Morinda citrifolia) fruit meal. JITV 20(3): 200-206. DOI: http://dx.doi.org/10.14334/jitv.v20i3.1187

Noni fruit is a medicinal plant with biological activity like antioxidant that could potentially be used as a feed additive in poultry. This research investigated the effect of noni fruit powder as feed additive on lipid profiles of blood and fatty acid compositions of meat of hybrid duck. One hundred and twenty 2-week-old hybrid ducks crossing between Peking and Khaki Campbell ducks were used in this study. They were randomly allotted to 24 experimental units. Each experimental unit was $70 \times 80 \times 40 \mathrm{~cm}$ in size and it was used for 5 ducks until they reached 56 days of age. Each unit was equipped with waterer and feeder. The ducks were raised on litter-type floor. The basal experimental diet was formulated according to the standards of National Research Council (1994). The design used for this study was experimental with 4 different treatments in 6 replications. The treatments were as follows: P0: basal feed without supplementation of noni fruit powder as control; P1: basal feed $+1 \%$ noni fruit powder; P2: basal feed $+2 \%$ noni fruit powder; P3: basal feed $+3 \%$ noni fruit powder. Data were analyzed by one-way of Completely Randomized Design ANOVA and if there was any significant effect then followed by Duncan's Multiple Range Test. Result showed that using noni fruit powder as feed additive had no significant effect (P $>0.05)$ on lipid profiles of blood and fatty acid composition of meat.
\end{abstract}

Key Words: Noni Fruit, Phytobiotic, Fatty Acid, Blood Lipid 


\section{INTRODUCTION}

Increasing consumer awareness on health requires the producer to provide safe, healthty, intact and kosher food products from animal. The food products containing relatively high saturated fatty acid such as cholesterol give negative effect to the consumers. They tend to avoid the saturated fatty acid and consume lowfatty acid food products from animal. Negative effects of saturated fatty acid consumption are obesity, diabetes, hypercholesterolemia, blood vessel constriction and coronary heart diseases (Fenita et al. 2011).

It is necessary to improve food quality such as fatty acid composition in the products. One attempt is utilizing natural feed additive (phytobiotic) in poultry diet. This material is bioactive substance of medicinal plants that have been widely studied as substitution of antibiotic and may improve fatty acid composition in food products. These plants contain bioactive substances such as alkaloids, flavonoids, glycosides, saponins, and tannins which may improve health and cure diseases (Sreenivs 1999).

Noni fruit (Morinda citrifolia) is a medicinal plant containing a number of bioactive substances with good effects for health. About 200 phytochemicals have been identified and isolated from various parts of noni plant. Chemical composition of the noni plant is different depending on part of the noni plant. Several groups of phytochemical which have been identified from noni plant are phenol compounds organic acid, anthraquinone, anthraquinone glycosides, carotenoids, ester, flavonoid, iridoids, ketones, lactones, lignans, nucleosedes, triterpenoids, sterol and several other minor compounds. Anthraquinone is the biggest fenol compound which has been identified and isolated from noni plant. Antioxidative activity from noni plant has also widely been reported (Zin et al. 2002; Mathivanan et al. 2005; Blanco et al. 2006; Singh 2012; Kumar et al. 2014.

Nurhayati et al. (2005) reported that use of noni fruit meal up to $10 \%$ in diet had no effect on feed intake, slaughter weight, and carcass weight of broiler chicken. Fenita et al. (2011) reported that provision noni fruit water up to $75 \mathrm{ml} / \mathrm{L}$ through drinking water did not affect percentage of carcass weight, abdominal fat, cooking loss and moisture content of meat but decreased fat content by $66.52 \%$ than control. Active substance in noni fruit water such as steroid is able to block cholesterol absorption, so that it may decrease cholesterol level in blood and fat level in meat. Sujana et al. (2007) reported that use of noni fruit meal (0.1$0.4 \%$ ) in diet was able to decrease cholesterol level in broiler chicken meat. Nishigaki \& Waspodo (2003) said that noni fruit was able to decrease Low Density
Lipoprotein (LDL) and increase High Density Lipoprotein (HDL). Adriani et al. (2014) reported that use of noni fruit juice by $0.3 \%$ and palm sugar (Arenga pinnata) around $0.2-0.4 \%$ through drinking water was able to decrease total cholesterol, LDL and triglyceride of blood serum of broiler chicken meat. Sally (2003) also said that use of noni fruit juice was able to increase HDL. Char (2005) said that antioxidant was able to prevent lipid (LDL) oxidation, so that oxidized LDL was not formed. Antioxidative activity on noni plant as feed additive was expected able to prevent free radical and reduce lipid oxidation on bird to produce better quality poultry products in terms of fatty acid profile.

This study was aimed to determine effect of noni meal on lipid profile of blood serum and fatty acid composition of hybrid duck meat.

\section{MATERIALS AND METHODS}

Ducks used in this study were hybrid ducks, a crossing between Peking male duck and Khaki Campbell female duck. Day old ducklings (DOD) of were obtained from a local hatchery. They were randomly allotted to 24 experimental units.

Table 1. Composition and nutrients contents of basal diet

\begin{tabular}{lc}
\hline \hline Feed Ingredients & Composition $(\%)$ \\
\hline Yellow corn & 56.52 \\
Soybean meal & 11.68 \\
Fine rice bran & 20.00 \\
Fish meal & 10.00 \\
Coconut oil & 1.50 \\
Premix** & 0.20 \\
\hline Total & 100
\end{tabular}

Diet nutrient contents

Metabolizable energy $\quad 3150.34$

$(\mathrm{Kcal} / \mathrm{kg})^{*}$

Crude protein $(\%)^{*} \quad 18.28$

Crude fat $(\%)^{*} \quad 5.93$

Crude fiber (\%)* $\quad 4.08$

(*) Analysis result of Laboratory of Nutrition and Animal Feed, Faculty of Animal Science, University of Brawijaya, Malang (2015) (**) Premix per kg consists of:

Vit A 12.000 IU; Vit D3 2.000 IU; Vit E 8 IU; Vit K3 2 mg Vit B1 2 mg; Vit B2 5 mg; Vit B6 05 mg; Vit B12 $0.012 \mathrm{mg}$ Vit C $25 \mathrm{mg}$; Ca-D-pantothenate $6 \mathrm{mg}$; Niacin $40 \mathrm{mg}$

Cholin Chloride $10 \mathrm{mg}$; Methionine $30 \mathrm{mg}$; Lysine $30 \mathrm{mg}$ Manganese $120 \mathrm{mg}$; Iron $20 \mathrm{mg}$; Iodine 0,2 mg; Zinc $100 \mathrm{mg}$ Cobalt $0.2 \mathrm{mg}$ 


\section{Lipid profile of blood serum}

Method used in this study was biological test designed based on Completely Randomized Design consisting of 4 treatments and 6 replications as follows: P0: Basal diet without noni fruit

$\mathrm{P} 1: \mathrm{P} 0+1 \%$ noni fruit meal

$\mathrm{P} 2: \mathrm{P} 0+2 \%$ noni fruit meal

$\mathrm{P} 3: \mathrm{P} 0+3 \%$ noni fruit meal

Noni fruit used was yellow ripe noni. Noni fruit meal production was started by cleaning the fruit by flowing water. The clean fruits were cut crosssection by $2-3 \mathrm{~cm}$ in thick and dried over in oven $45^{\circ} \mathrm{C}$ for $2-3$ days. Dried noni fruits were ground finely and sifted using 75 meshes $(0.75 \mathrm{~mm})$. The hybrid ducks were kept in litter cage by $70 \mathrm{~cm} \mathrm{X} 80 \mathrm{~cm} \mathrm{X} 40 \mathrm{~cm}$. Each cage was filled up by 5 ducklings and grouped by treatments. Each cage was equipped with waterer and feeder. They were fed by the allocated treatments ad libitum in the morning (07.00 am) and afternoon (03:00 $\mathrm{pm})$. Drinking water was given ad libitum. Treatments application and data collection were conducted for 6 weeks. Treatment diet was mixed according to basal diet composition based on broiler duck nutrient requirement in the NRC (1994). Basal diet composition and nutrient contents used in this study were presented in Table 1.

Blood sample collection was carried out on 1 duck from each replication at the end of study (after 6 weeks). Blood was taken from wing vena by $3 \mathrm{ml}$ syringe and then was placed in the sample tube. Blood sample was placed in Styrofoam box containing ice cubes and transported to the laboratory. In the laboratory, blood sample was placed in $4^{\circ} \mathrm{C}$ refrigerator for 12 hours before it was centrifuged by $3500 \mathrm{rpm}$ for 10 minutes. Supernatant, in the form of serum was taken using sterile pipette and placed in eppendorf tube for further analysis. Analysis of lipid profile of blood serum consisted of triglyceride level, total cholesterol, Low Density Lipoprotein (LDL), and High Density Lipoprotein (HDL) using CHOD-PAP method (Cholesterol Oxidase Phenylperoxidase Amino Phenozonphenol) based on DSI (2005).

\section{Fatty acid composition}

Meat sample collection was done by randomly slaughtering the ducks in the end of maintenance $(8$ weeks) from each replication in every treatment. Meat samples used were from chest and thigh. Testing procedure of meat fatty acid composition was according to AACC (1983). Testing steps were consisting of soxhlet extraction to produce fat in the form of oil. Methylation was done by refluxing $0.02 \mathrm{~g}$ fat over a water bath $\left(80^{\circ} \mathrm{C}\right)$ with $5 \mathrm{ml} \mathrm{NaOH}$ in methanol and 5 $\mathrm{ml}$ bourtiflourid-metanol respectively for 20 minutes, and than were removed and cooled. The next step was addition of $2 \mathrm{ml}$ saturated $\mathrm{NaCl}$ and $5 \mathrm{ml}$ hexane and homogenized. Hexane lining was pipetted and put into eppendorf tube. Chromatography gas was injected into 2-5 $\mu \mathrm{L}$ sample. Fatty acid identification using the chromatography gas with column temperature at $200^{\circ} \mathrm{C}$, initial temperature at $150^{\circ} \mathrm{C}$, final temperature at $180^{\circ} \mathrm{C}$, limit pressure at $3000 \mathrm{psi}$, N2 mobile phase, stationer phase of diethylene glycol succinate (DEGS) powder, detector FID $250^{\circ} \mathrm{C}$, column length $40 \mathrm{~m}$ and diameter in column $1.2 \mathrm{~mm}$. Standards of fatty acid used were capric acid (C10: 0), lauric acid (C12: 0), myristic acid (C14: 0), palmitic (C16: 0), stearic (C18: 0), oleic (C18: 1), linoleic (C18: 2 ) and linolenic acid (C18: 3). Calculation of fatty acid referred to Dewi (2009) as follow:

The number of fatty acid A (mg/g):

$=\frac{\text { Weight SI on sample }(\mathrm{mg})}{\text { Weight of sample }(\mathrm{g})} \mathrm{XRF} \times \frac{\text { Area of sample fatty acid }}{\text { Area standar }}$

RF fatty acid A:

$=\frac{\text { SI area }}{\text { Weight of sample }(g)} \times \frac{\text { Fatty acid consentration of standard }}{\text { Fatty acid area A of standard }}$

where:

SI = Internal standard C17 (margarat acid)

$\mathrm{RF}=$ Factor response

\section{Statistics analysis}

Data obtained were tabulated using excel and analyzed using Completely Random Design if there was significant or very significant effect then followed by Duncan's Multiple Range Test with following mathematical model:

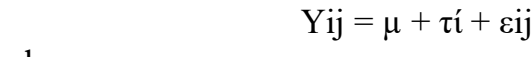

where:

Yij = Observation result of change of noni fruit meal use $i_{\text {th }}$ with $j$-replication

$\mu \quad=$ Average observation

$\tau i=$ Effect of $\mathrm{i}$-treatment

cij $=$ Effect of $\mathrm{i}$-trial error and $\mathrm{j}$-replication

$\mathrm{i}=1,2,3$, and 4

$\mathrm{j}=1,2,3,4,5$, and 6 


\section{RESULTS AND DISCUSSION}

\section{Lipid profile of blood serum}

Effects of noni fruit meal to lipid profile of blood serum is presented in Table 2. Noni fruit meal used as feed additive had no significant effect $(\mathrm{P}<0.05)$ on triglyceride, total cholesterol, HDL and LDL. Administration of noni fruit meal up to $3 \%$ in diet was not able to decrease triglyceride level and total cholesterol of duck's blood serum. This result is not in accordance with Adriani et al. (2014) who reported that there was a decrease of triglyceride and total cholesterol of broiler chicken's blood serum by administrating noni fruit juice through the drinking water. Coumarin compound increases secretion of biliary acid and oxide nitrite compound, which will secrete cholesterol in the blood through feces. Beta-carotene and flavonoid also have role in decrease of cholesterol level. Sujana et al. (2007) reported that cholesterol content of broiler chicken meat experienced a decrease by administrating diet containing of noni fruit meal. Fat level was also decreased in broiler chicken meat by administrating noni fruit water as reported by Fenita et al. (2011).

Active compound in noni fruit is one of causes in the decrease of level of triglyceride and cholesterol in the blood serum. Administrating noni fruit meal up to $3 \%$ in diet has not been able to decrease level of triglyceride and cholesterol of hybrid duck's blood serum. This shows that active compound in noni fruit meal is unable to reduce lipid oxidation and prevent cholesterol formation.

Phytosterol is plant fat which may not be absorbed by digestive track. The phytosterol may increase partly of biliary acid, so that availability of biliary acid is dwindling. Cholesterol from diet may not be absorbed by intestinal wall because it reacts with the biliary acid (Anwar \& Piliang 1992). Phenol compound, especially flavonoid, may prevent intestinal michellium formation, a place of biliary acid absorption, so that cholesterol may not be absorbed by digestive track and then immediately removed through feces (Kusnadi 2004).

This research showed that administrating noni fruit meal up to $3 \%$ was unable to decrease LDL level or increase HDL level of hybrid duck's blood serum. This shows that active compound in noni fruit meal was unable to prevent lipid oxidation. This result was not in line with research result of Adriani et al. (2014) who said that administration of noni fruit juice and sugar palm in the drinking water of broiler chicken may decrease total cholesterol, LDL, and triglyceride of blood serum. As reported by Fondevilla et al. (2010) that administration of noni fruit meal to mouse decreased level of cholesterol, triglyceride, LDL and HDL in blood serum. Xeronim compound decreases level of cholesterol in blood because it stimulates insulin hormone formation. Insulin hormone is able to increase the number of receptor of Very Low Density Lipoprotein (VLDL), where this compound will bring triglyceride-rich particles in the bloodstream from liver to body cell.

\section{Composition of meat fatty acid}

Composition of fatty acid of duck meat supplemented by noni fruit meal is presented in Table 3 . Results showed that duck meat contained 11 fatty acids belonging to 8 saturated fatty acids namely: Butyric (C4), caproic (C6), caproate (C8), caprate (10), lauric (C12), myristic (C14), Palmitate (C16-0) and stearic $(\mathrm{C} 18-0)$ and 3 unsaturated fatty acids namely: Oleic (C18-1), linoleic (C18-2), and linoleic (18-3). Control treatment (without noni fruit meal) had fewer fatty acids than other treatments. There were several undetected sort-chain saturated fatty acids in the control treatment such as Butyric (C4), caproic (C6), caproate (C8) and caproate (10).

Duck meat has higher unsaturated fatty acid content compared to saturated fatty acid. This is in line with Aronal et al (2012) who said that Muscovy, Peking duck and wild duck had higher unsaturated fatty acid

Table 2. Lipid profile of blood serum of hybrid duck supplemented by noni fruit meal in diet

\begin{tabular}{lcrrr}
\hline \hline Parameter & PO & \multicolumn{1}{c}{ P1 } & P2 & P3 \\
\hline Cholesterol (mg/dL) & $203.33 \pm 43.82$ & $197.00 \pm 60.11$ & $186.33 \pm 65.06$ & $192.00 \pm 58.03$ \\
Triglyceride (mg/dL) & $155.33 \pm 43.82$ & $191.33 \pm 11.40$ & $183.00 \pm 11.45$ & $172.33 \pm 91.78$ \\
HDL (mg/dL) & $111.40 \pm 43.82$ & $91.63 \pm 21.63$ & $92.77 \pm 28.76$ & $94.10 \pm 29.71$ \\
LDL (mg/dL) & $60.87 \pm 43.82$ & $67.10 \pm 21.61$ & $56.97 \pm 23.69$ & $56.77 \pm 22.57$ \\
\hline
\end{tabular}

$\mathrm{P} 0=$ Basal diet without noni fruit meal (control)

$\mathrm{P} 1=$ Basal diet $+1 \%$ noni fruit meal

$\mathrm{P} 2=$ Basal diet $+2 \%$ noni fruit meal

$\mathrm{P} 3=$ Basal diet $+3 \%$ noni fruit meal 
Table 3. Composition of fatty acid (mg/g) of hybrid duck meat supplemented by noni fruit meal in diet

\begin{tabular}{|c|c|c|c|c|}
\hline \multirow{2}{*}{ Fatty acid } & \multicolumn{4}{|c|}{ Treatment } \\
\hline & P0 & $\mathrm{P} 1$ & $\mathrm{P} 2$ & P3 \\
\hline Butyrate (C4) & - & - & $0.01 \pm 0.00$ & $0.02 \pm 0.00$ \\
\hline Caproate (C6) & - & $0.01 \pm 0.00$ & $0.01 \pm 0.00$ & $0.01 \pm 0.00$ \\
\hline Caprilate (C8) & - & $0.01 \pm 0.00$ & $0.01 \pm 0.00$ & \\
\hline Caprate (10) & - & - & $0.01 \pm 0.00$ & - \\
\hline Laurate (C12) & $0.04 \pm 0.00$ & $0.01 \pm 0.00$ & $0.02 \pm 0.00$ & $0.01 \pm 0.00$ \\
\hline Myristate (C14) & $0.09 \pm 0.01$ & $0.09 \pm 0.01$ & $0.11 \pm 0.02$ & $0.09 \pm 0.00$ \\
\hline Palmitate (C16-0) & $3.85 \pm 0.41$ & $4.02 \pm 0.68$ & $4.60 \pm 0.57$ & $4.05 \pm 0.29$ \\
\hline Stearate $(\mathrm{C} 18-0)$ & $1.32 \pm 0.12^{\mathrm{a}}$ & $1.48 \pm 0.25^{\mathrm{ab}}$ & $1.89 \pm 0.17^{\mathrm{c}}$ & $1.75 \pm 0.16^{\mathrm{bc}}$ \\
\hline Total ALJ & $5.30 \pm 0.49$ & $5.61 \pm 0.95$ & $6.65 \pm 0.66$ & $5.94 \pm 0.44$ \\
\hline Oleate (C18-1) & $7.04 \pm 0.83$ & $7.03 \pm 1.36$ & $7.95 \pm 0.94$ & $7.16 \pm 0.77$ \\
\hline Linoletae (C18-2) & $2.32 \pm 0.28$ & $2.32 \pm 0.36$ & $2.85 \pm 0.33$ & $2.54 \pm 0.16$ \\
\hline Linoleate (C18-3 & $0.09 \pm 0.01$ & $0.08 \pm 0.01$ & $0.10 \pm 0.02$ & $0.07 \pm 0.01$ \\
\hline Total ALTJ & $9.45 \pm 1.15$ & $9.43 \pm 1.70$ & $10.90 \pm 1.76$ & $9.77 \pm 0.91$ \\
\hline Ratio ALTJ/ALJ & $1.78 \pm 0.14$ & $1.67 \pm 0.16$ & $1.49 \pm 0.18$ & $1.64 \pm 0.04$ \\
\hline
\end{tabular}

Different superscripts in the same row show significant $(\mathrm{P}<0.05)$ differences - (undetected)

ALJ = Saturated fatty acid

ALTJ = Unsaturated fatty acid

$\mathrm{P} 0 \quad=$ Basal diet without noni fruit meal (control)

$\mathrm{P} 1=$ Basal diet $+1 \%$ noni fruit meal

P2 $=$ Basal diet $+2 \%$ noni fruit meal

$\mathrm{P} 3=$ Basal diet $+3 \%$ noni fruit meal

composition than saturated fatty acid. Pikul et al (1996) said that bird had better fatty acid content than other animals because they had $60-70 \%$ polyunsaturated fatty acid (PUFA) and 45-50\% monounsaturated fatty acid (MUFA). Fatty acid profile of bird is affected by diet content fed to bird. Bird may synthesize saturated fatty acid and the MUFA in the diet, except fat. Cho et al. (2005) said that fatty acid composition in meat and fat tissue of animal was affected by several factors such as: species and breed, sex, and diet composition.

In this study, administration of noni fruit meal in diet did not affect $(\mathrm{P}>0.05)$ overall fatty acid composition of duck meat, saturated fatty acid, and ratio of saturated fatty acid and unsaturated fatty acid (STF/UFA ratio), except stearat (C18-0) which showed significant effect $(\mathrm{P}<0.05)$

Based on result of further analysis of DMRT, administration of noni fruit meal (2 and 3\%) showed higher stearate acid than the control. This result shows that administration of noni fruit meal up to $3 \%$ in diet was unable to change composition of meat fatty acid. Active compound in the noni fruit meal was unable to prevent lipid oxidation, so that duck meat fatty acid composition was not different from the control. Different result was reported by Rukmiasih et al. (2011) who said that composition of unsaturated fatty acid of duck meat increased by administration of beluntas plant (Pluchea indica L) combined with vitamin E compared with control (without vitamin E). This shows that antioxidant activity of natural material such as the beluntas plant and vitamin $\mathrm{E}$ was more effective in protecting the unsaturated fatty acid from excessive lipid oxidation. Unsaturated fatty acid is a compound that is susceptible to auto-oxidation. Lipid oxidation is the main cause of bird products damage. Antioxidant compound is a component that may retard and prevent lipid oxidation by free radical. Alloui et al. (2014) said that antioxidant in several herbal plants was able to protect lipid in diet from oxidation, so that the products from animal became more stable to the oxidation. Purba et al. (2010) said that composition of fatty acid of boiled duck meat supplemented by antioxidant showed higher total composition of unsaturated fatty acid than the total of saturated fatty acid.

Content of stearate acid was increased by administration of noni fruit meal. This was caused by fatty acid content of noni seed oil in the noni fruit meal. Timotius (2003) said that noni seed consisting of fewer oil than other vegetable oil-source plants. Noni seed oil consists of many unsaturated fatty acid such as linoleate 
and oleat acids about $75 \%$. The rest, about $25 \%$ was saturated fatty acids such as palmitate and stearate acids. Composition of this fatty acid is also related to bioactive compound in the noni seed. Singh (2012) said that in noni fruit, there was an antaquinine substance which is an acid material and closely related to cathechol (acid). Noni meal may affect $\mathrm{pH}$ of digestive track to become more acidic. Acidic condition will cause activity of lipase enzyme to be restricted, so that it causes reducing of fat digestion and fewer body fat forming. Furthermore, it is said that noni meal has direct role in blood vessel and may neutralize fat which will be transported to meat forming.

\section{CONCLUSION}

Administration of noni fruit meal up to $3 \%$ in diet has not been able to change lipid profile of blood serum and composition of fatty acid of hybrid duck. Stearat acid experienced an increase by administration of noni fruit meal.

\section{REFERENCES}

[AACC] American Association of Cereal Chemist. 1983. Approved methods of the American Association of Cereal Chemist. 8th ed. USA: American Association of Cereal Chemist.

Adriani L, Widjastuti T, Sujana E, Mushawwir A, Yulianti A. 2014. Effect of Noni (Morinda clitrifolia L) juice and Palm sugar (Arenga pinnata) supplementation in drinking water on lipid profile broiler chicken. Pak J Nutr. 14:531-534.

Alloui MN, Agabou A, Alloui N. 2014. Application of herb and phytogenic feed additive in poultry production- a review. Glob J Anim Sci Res. 2:234-243.

Anwar H, Piliang WG. 1992. Biokimia dan fisiologi gizi. Bogor (Indones): Pusat Antar Universitas Ilmu Hayati, Institut Pertanian Bogor.

Aronal AP, Huda N, Ahmad R. 2012. Amino acid and fatty acid profile of Peking and Muscovy duck meat. Int $\mathrm{J}$ Poult Sci. 11:229-236.

Blanco YC, Vaillant F, Perez AM, Reynes M, Brillouet JM, Brat P. 2006. The Noni Fruit: A Review of Agriculture Research, Nutritional and Teurapeutic Properties. J Food Composition Anal. 19:645-654.

Char MD. 2005. The pathophysiology of acute coronary syndromes. J Emerg Med Cardic Res. 1:1-6.

Cho SH, Park BY, Kim JH, Hwang IH, Kim JH, Lee JM. 2005. Fatty acid profiles and sensory properties of longissimus dorsi, triceps brachii, and semimembranosus muscles from Korean Hanwoo and Australian Angus beef. Asian-Aust J Anim Sci. 18:1786-1793.
Dewi. 2009. Komposisi kimia, asam lemak dan kolesterol udang ronggeng (Harpiosquilla raphidea) akibat perebusan (Tesis). [Bogor (Indones)]: Institut Pertanian Bogor.

[DSI] Diagnostic System International. 2005. Cholesterol FS. Diagnostic reagent for quantitative in vitro determination of cholesterol in serum or plasma on photometric system. DiaSys Diagnostic System Gmbh Alte Strasse 965558 Holzheim, German.

[DSI] Diagnostic System International. 2005. HDLCholesterol. DiaSys Diagnostic System Gmbh Alte Strasse 965558 Holzheim, German.

[DSI] Diagnostic System International. 2005. LDLCholesterol. DiaSys Diagnostic System Gmbh Alte Strasse 965558 Holzheim, German.

Fenita Y, Warnoto, Nopis A. 2011. Pengaruh pemberian air buah mengkudu terhadap kualitas karkas ayam pedaging. Jurnal Sain Peternakan Indonesia. 6:143-150.

Fondevilla R, Holgado R, Lopez HN, Rodriguez J, Trinidad C Velasquez J. 2010. Effect of Morinda citrifolia (Noni) fruit powder in the lipid profile of Sparague-Dawley rats. The STETH. 4:33-40.

Kumar SNK, M Suresh, SA Kumar P Kalaiselvi. 2014. Bioactive Compounds, Radical Scavering, Antioxidant Properties and FTIR Spectroscopy Study of Morinda clitrifolia Fruit Extracts. Int J Curr Microbiol Appl Sci. 3:28-42.

Kusnadi E. 2004. Peranan antaran (Centella asiatica L) dan Vitamin C sebagai penangkal cekaman panas ayam broiler dalam ransum yang mengandung hidrolisat bulu ayam (Disertasi). [Bogor (Indones)]: Institut Pertanian Bogor.

Mathivanan N, Surendiran G, Srinivasan K, Sagadevan E, Malarvizbi K. 2005. Review on the current scenario of Noni research: Taxonomy, distribution, chemistry, medicanal and therapeutic value of Morinda citrifolia. Int J Noni Res. 1:1-16.

[NRC] National Research Council. 1994. Nutrient requrements of poultry. 9th Revision Edition. Washington DC (USA): National Academy Press. p. 107-108.

Nishigaki R, Waspodo. 2004. Sehat dengan Mengkudu. Jakarta (Indones): MSF.

Nurhayati, Nelwida, Marsadayanti. 2005. Pengaruh Penggunaan Tepung Buah Mengkudu dalam Ransum terhadap Bobot Karkas Ayam Broiler. J Indones Trop Anim Agric. 30:96-101.

Pikul J. 1996. Lipidy miesa drobiu. Gosp Mie-sna. 48:8-34.

Purba M, Laconi EB, Keraten P, Wijaya CH, PS Hardjosworo. 2010. Kualitas sensori dan komposisi asam lemak daging itik lokal jantan dengan suplementasi santoquin, vitamin $\mathrm{E}$ dan $\mathrm{C}$ dalam ransum. JITV. 15:47-55. 
Rukmiasih, Hardjosworo PS, Keraten PP, Mattaputty PR 2011. Penggunaan beluntas, vitamin $\mathrm{C}$ dan $\mathrm{E}$ sebagai antioksidan untuk menurunkan off-odor daging itik Alabio dan Cihateup. JITV. 16:9-16.

Sally E. 2003. Effect of infusion Noni on Total Cholesterol, Triglycerides, LDL, and HDL blood serum of Mice (Mus musculus) after administration high fat feed (Thesis). [Surabaya (Indones)]: Airlangga University.

Singh DR. 2012. Morinda citrifolia L: A review of the scientific validation for its nutritional and therapeutic properties. J Diabetes Endocrinol. 3:77-91.

Sreenivs P. 1999. Herbal healing. Far Eastern Agriculture. September/October 1999:30-32.
Sujana E, Darana S, Garnida D, Widjastuti T. 2007. Efek Pemberian Ransum Mengandung Tepung Buah Mengkudu (Morinda clitrifolia Linn.) Terhadap Kandungan Kolesterol, Persentase Karkas dan Lemak Abdominal Ayam Broiler. Prosiding Seminar Nasional Teknologi Peternakan dan Veteriner. Bogor (Indones): Pusat Penelitian dan Pengembangan Peternakan. hlm. 556-561.

Timotius KH. 2003. Komposisi minyak biji Mengkudu (Morinda citrifolia L). J Teknologi dan Industri Pangan. 14:262-265.

Zin M, Abdul-Hamid A, Osman A. 2002. Antioxidant activity of extract from mengkudu root, fruit and leaf. Food Chem.78:227-231. 